\title{
Semilobar holoprosencephaly
}

INSERM

\section{Source}

INSERM. (1999). Orphanet: an online rare disease and orphan drug data base. Semilobar holoprosencephaly. ORPHA:220386

Semilobar holoprosencephaly is one of the classical forms of holoprosencephaly (HPE; see this term) in which the left and right frontal and parietal lobes are fused and the interhemispheric fissure is only present posteriorly. 